\title{
Stem cells in genetically-engineered mouse models of prostate cancer
}

\author{
Maho Shibata and Michael M Shen \\ Departments of Medicine, Genetics and Development, Urology, and Systems Biology, Herbert Irving Comprehensive \\ Cancer Center, Columbia University Medical Center, New York, New York 10032, USA
}

Correspondence

should be addressed

to $M$ M Shen

Email

mshen@columbia.edu

\begin{abstract}
The cancer stem cell model proposes that tumors have a hierarchical organization in which tumorigenic cells give rise to non-tumorigenic cells, with only a subset of stem-like cells able to propagate the tumor. In the case of prostate cancer, recent analyses of genetically engineered mouse (GEM) models have provided evidence supporting the existence of cancer stem cells in vivo. These studies suggest that cancer stem cells capable of tumor propagation exist at various stages of tumor progression from prostatic intraepithelial neoplasia (PIN) to advanced metastatic and castration-resistant disease. However, studies of stem cells in prostate cancer have been limited by available approaches for evaluating their functional properties in cell culture and transplantation assays. Given the role of the tumor microenvironment and the putative cancer stem cell niche, future studies using GEM models to analyze cancer stem cells in their native tissue microenvironment are likely to be highly informative.
\end{abstract}

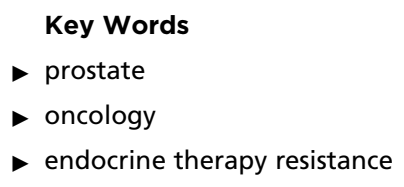

Endocrine-Related Cancer (2015) 22, T199-T208

\section{Introduction}

For the past 70 years, androgen-deprivation therapy has remained the mainstay of treatment for prostate cancer. Although most prostate cancers initially respond to androgen deprivation, many will ultimately progress to lethal castration-resistant disease. The widespread usage of next-generation anti-androgen agents continues to highlight the clinical significance of the emergence of treatment-resistant disease. Thus, understanding the molecular mechanisms that promote tumor propagation during the progression of prostate cancer to castrationresistance is of fundamental importance for the development of reliable biomarkers and effective treatments.

Studies using genetically engineered mouse (GEM) models have revealed that the normal prostate contains castration-resistant stem/progenitor cells that retain their stem cell properties after androgen deprivation. These findings raise the possibility that similar stem cell populations that resist castration may also exist in prostate tumors and contribute to the emergence of castrationresistant disease. Here, we review findings from studies using GEM models to identify cancer stem cells in prostate cancer.

\section{Stem/progenitor cells in the normal prostate epithelium}

In both the mouse and human adult prostate epithelium, there are three primary cell types, corresponding to luminal cells, basal cells, and neuroendocrine cells, which can be distinguished by morphology as well as marker gene expression (Shen \& Abate-Shen 2010). In particular, luminal epithelial cells express cytokeratins 8 (CK8) and CK18, as well as high levels of androgen receptors (ARs), whereas basal cells express p63, CK5, CK14, and low levels of AR. Luminal cells also produce secretory proteins such as prostate-specific antigen (PSA)

This paper forms part of a thematic review section on Stem Cells and Cancer. The guest editor for this section was Dean Tang, The University of Texas MD Anderson Cancer Center, Smithville, TX USA Gaded from Bioscientifica.com at 04/26/2023 01:31:01PM 
in humans and probasin in mice. The rare neuroendocrine cells are epithelial cells that display neuronal-like processes and express neural markers such as synaptophysin and chromogranin A (Abrahamsson \& di Sant'Agnese 1993, Terry \& Beltran 2014). Finally, a population of basally localized cells that co-express luminal and basal CK are termed 'intermediate' cells (De Marzo et al. 1998, Xue et al. 1998), but whether these cells constitute a distinct functional cell type remains unclear.

Following androgen deprivation by surgical or chemical castration, the prostate epithelium regresses, with extensive apoptosis of luminal cells (Evans \& Chandler 1987, Isaacs et al. 1992). However, on readministration of androgens, the mouse prostate can regenerate to its original size and is histologically indistinguishable from the hormonally intact state. Importantly, the mouse prostate can undergo multiple rounds of regression and regeneration in response to androgen deprivation and restoration, indicating the existence of a castration-resistant stem cell population within the regressed prostate epithelium (Isaacs 1985, Tsujimura et al. 2002). Notably, an analysis during serial regression and regeneration of BrdU-label retaining cells, which are presumed to be enriched for stem/progenitor cells, showed that these label-retaining cells are highly enriched in both basal and luminal populations in the proximal region of the prostate, near the junction with the urethra (Tsujimura et al. 2002).

To date, there is substantial evidence supporting the existence of stem/progenitor activity in both the basal as well as luminal compartments, with the results potentially being assay-dependent (Tsujimura et al. 2002, Lawson et al. 2007, Goldstein et al. 2008, Wang et al. 2009, 2013, Chua et al. 2014, Karthaus et al. 2014). Lineage-tracing analyses of prostate organogenesis have shown the existence of multipotent basal progenitors that generate basal, luminal, and neuroendocrine progeny, as well as unipotent luminal progenitors that only generate luminal progeny (Ousset et al. 2012, Pignon et al. 2013). During neonatal development, the differentiation of basal progenitors into luminal cells appears to proceed through a transitional intermediate cell state (Ousset et al. 2012). In contrast, the adult prostate epithelium is mostly maintained by unipotent luminal and basal progenitors (Choi et al. 2012, Lu et al. 2013, Wang et al. 2013). Similarly, the luminal and basal compartments are also thought to be largely independent during androgen-mediated regeneration (Liu et al. 2011, Choi et al. 2012, Wang et al. 2013). However, luminal as well as basal bipotential populations have also been identified in regenerating prostate epithelium. Notably, a rare Nkx3.1-expressing castration-resistant luminal population (CARN) is bipotential and can self-renew during androgen-mediated regeneration (Wang et al. 2009). Recent studies have also suggested the existence of bipotential basal progenitors that undergo asymmetric cell divisions to generate luminal and basal daughter cells during regeneration (Wang et al. 2013, 2014a, 2015, Lee et al. 2014). Interestingly, the fates of daughter cells from a dividing basal progenitor are correlated with mitotic spindle orientation, as asymmetric divisions occur when the spindle is oriented vertically relative to the basement membrane (Wang et al. 2014a).

Other approaches for identifying stem cell populations in the normal WT prostate epithelium have identified multipotent basal cells using cell culture assays as well as renal graft methods that involve the transplantation of epithelial cells together with supporting urogenital mesenchyme (Xin et al. 2003, Lukacs et al. 2010). Initial studies used flow sorting to show that cells expressing high levels of $S c a 1$ are enriched in the proximal prostate and display stem/progenitor properties in culture and in graft assays (Burger et al. 2005, Xin et al. 2005, Goto et al. 2006). Subsequent studies have further defined a population of $\mathrm{Lin}^{-} \mathrm{Sca}-1^{+} \mathrm{CD}_{4} 9 \mathrm{f}^{\text {high }}$ (LSC ${ }^{\text {high }}$ ) cells that displays stem-like properties and can be further enriched using the Trop2 marker (Lawson et al. 2007, Goldstein et al. 2008, Lukacs et al. 2010). Notably, the LSC ${ }^{\text {high }}$ population consists of basal cells (Mulholland et al. 2009, Wang et al. 2013), which may be consistent with the plasticity of basal cells observed in ex vivo assays as well as in vivo models of prostate cancer and inflammation (Choi et al. 2012, Lu et al. 2013, Wang et al. 2013, Kwon et al. 2014a).

\section{Identification of putative cancer stem cells in prostate cancer}

In the cancer stem cell model, tumors contain distinct cell populations that differ in their genetic/epigenetic features and thus display intratumor heterogeneity. The model proposes that these cell populations are functionally distinct, such that tumorigenic stem cells can give rise to non-tumorigenic cells, with only the stem cell population able to self-renew and thereby propagate the tumor. Thus, cancer stem cells can behave in an analogous manner to normal stem cells in an untransformed tissue, except that their proliferation and differentiation are dysregulated. In principle, this hierarchical organization of tumors has important therapeutic implications. If only cancer stem

Published by Bioscientifica Ltd. 
cells possess tumor-propagating abilities, then only this population would need to be targeted for therapy. However, if most or all tumor cells possess tumorpropagating abilities, then every tumor cell would need to be eliminated.

While the cancer stem cell model is conceptually well defined, there are substantial experimental challenges associated with investigating the validity of this model for a given tumor. To assay their functional differences, both cancer stem cell and non-cancer stem cell populations must be identified, and most studies to date have isolated these cell populations for ex vivo analyses using cell culture and graft assays. In the case of solid tumors, tumor cells are generally dissociated using mechanical and/or enzymatic methods and sorted by flow cytometry using cell surface markers that enrich for putative cancer stem cells. Following their isolation, the putative cancer stem cells can be compared with non-stem cells from the same tumor for their functional activity.

Many cancer stem-like cells that have been identified to date express similar markers as normal non-cancerous stem cells. However, cancer stem cells may or may not be related to a normal stem cell, which may depend in part on the cell of origin of a tumor, which is defined as the normal untransformed cell type from which the tumor arises. In many tumor types, the cell type of origin corresponds to a normal stem cell, but there is also substantial evidence for cells of origin that are not stem/progenitor cells (Visvader 2011, Blanpain 2013). Thus, if the cell type of origin is not a stem cell, it is conceivable that the putative cancer stem cell derived from it might not share specific markers with normal tissue stem cells. In studies of the mouse and human prostate, it is currently unresolved whether luminal cells or basal cells, or both, may serve as cells of origin (Goldstein et al. 2010a, Lawson et al. 2010, Choi et al. 2012, Lu et al. 2013, Wang et al. 2013), although lineagetracing studies using multiple GEM models indicate that luminal cells are generally favored as the cell of origin (Wang et al. 2014b).

Whether stem-like cells that function to maintain and propagate tumors exist in prostate cancer, and whether such cells display basal-like or luminal-like properties, has been a topic of great interest (Goldstein et al. 2010b, Maitland et al. 2011, Wang \& Shen 2011, Chen et al. 2013). Notably, most prostate tumors display a luminal epithelial phenotype, because prostate adenocarcinoma is identified histologically by an absence of basal cells (Brawer et al. 1985, Wojno \& Epstein 1995, Weinstein et al. 2002). The luminal phenotype of prostate cancer is consistent with the hypothesis that stem cells should have luminal properties but does not exclude the possibility that rare stem cells with basal features may exist. Furthermore, as may be the case for the normal prostate, it is conceivable that multiple stem-like populations may exist in prostate tumors.

Finding robust and reproducible methods to assess the activity of prostate cancer stem cells has been a principal challenge in the field. Both cell culture-based assays and transplantation assays have been used to assess stem/ progenitor activity (Shibata \& Shen 2013) (Fig. 1). A major approach that has been utilized for assaying prostate cancer stem cell activity has been the prostasphere assay, a three-dimensional culture method in which cells are suspended in a Matrigel matrix together with prostate epithelial growth (PrEGM) media, which allows cells to self-renew and differentiate (Lawson et al. 2007, Xin et al. 2007, Lukacs et al. 2010). In addition, tumor propagation can be evaluated by orthotopic, intravenous, or subcutaneous transplantation into immunocompromised animals in the absence of exogenous stromal tissue or in combination with urogenital sinus mesenchyme in renal grafts (Lukacs et al. 2010, Lawrence et al. 2013, Shibata \& Shen 2013). However, both methods have been severely limited for analysis of primary human patient samples because it has not been possible to culture primary tumor samples using the prostasphere assay (Garraway et al. 2010). Furthermore, it has been difficult to perform high efficiency xenografts using primary prostatectomy tissue (Li et al. 2009, Toivanen et al. 2013), perhaps due to the generally indolent phenotype of most prostate tumors.

Another challenge for the analysis of cancer stem cells arises from the selective pressures experienced by clones within a tumor during cancer progression, as individual clones accumulate distinct genetic and/or epigenetic changes (Greaves \& Maley 2012, Kreso \& Dick 2014). Such mutations can be either neutral or advantageous, resulting in the expansion of certain clones and the reduction of others, leading to clonal evolution of the tumor. In prostate cancer, androgen-deprivation therapies lead to clonal reduction and provide selective pressures such that castration-resistant clones can become dominant (Fig. 2). As tumors evolve, the cancer stem cells may themselves change genotypically and phenotypically (Anderson et al. 2011, Greaves \& Maley 2012). Thus, clonal evolution may alter the phenotype and functional properties of cancer stem cells during tumor progression, which may create difficulties for experimental interpretation.

Published by Bioscientifica Ltd. 

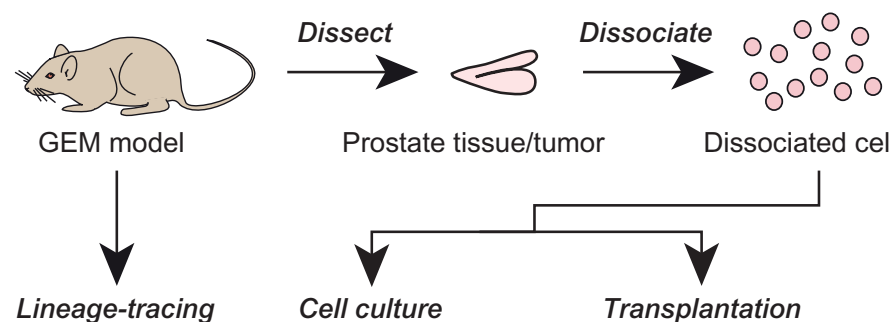

Prostate tissue/tumor Dissociated cells

Lineage-tracing

Cell culture

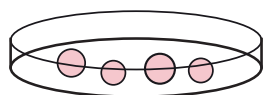

2D culture: colony formation

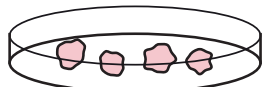

3D culture: prostaspheres and organoids
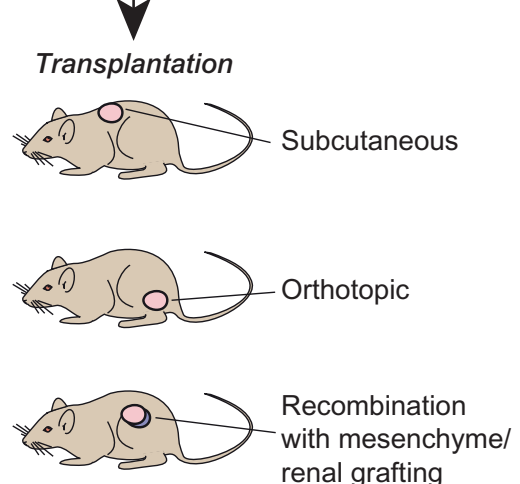

Figure 1

Assays for cancer stem cells from genetically engineered mouse (GEM) models of prostate cancer. Prostate tumor cells from GEM models can be dissociated and flow sorted to assay for tumor propagation in cell culture

or by transplantation into immunodeficient mice. The fate of candidate cancer stem cells can be also directly assessed by in vivo lineage tracing.

\section{GEM models of prostate cancer}

Over the past 20 years, numerous GEM models have been developed that model various stages of prostate cancer progression, from the precursor state known as prostatic intraepithelial neoplasia (PIN) to adenocarcinoma as well as advanced metastatic and castration-resistant disease. These GEM models usually incorporate inactivation of tumor suppressor genes such as Nkx3.1, Pten, and Trp53 and/or overexpression of oncogenes such as c-Myc, Erg, and K-ras (Shappell et al. 2004, Irshad \& Abate-Shen 2013, Ittmann et al. 2013). Notably, alterations such as

down-regulation of NKX3.1, mutation of Pten, and increased expression of ERG are frequently observed in human prostate cancers (Taylor et al. 2010, Barbieri et al. 2012, Baca et al. 2013, Robinson et al. 2015), and consequently these models may be relevant for studies of prostate tumorigenesis.

Although many GEM models of prostate cancer have been developed, it is important to note that some features of the human prostate are intrinsically difficult to model in mice. In particular, the mouse prostate is comprised of distinct anterior, ventral, dorsal, and lateral lobes, whereas

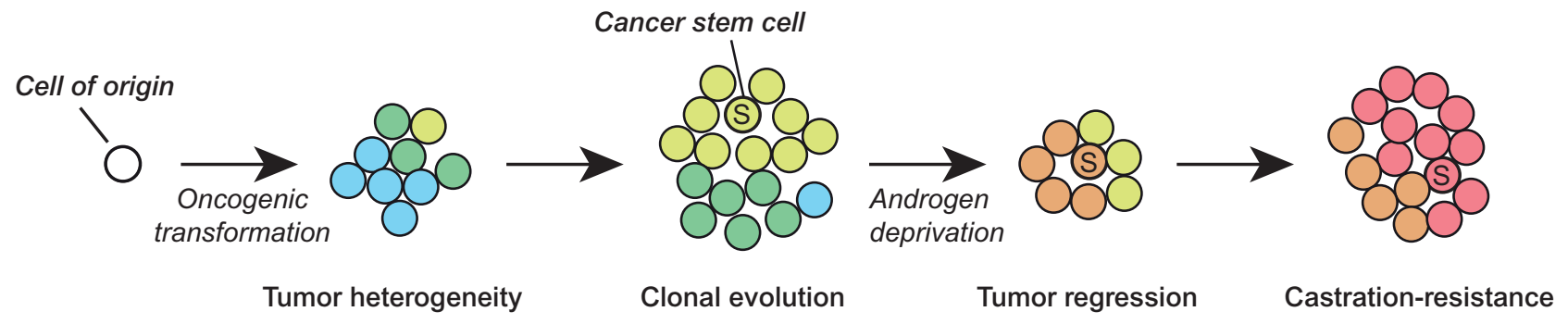

\section{Figure 2}

Clonal evolution of cancer stem cells in prostate cancer. Intratumor heterogeneity in prostate tumors increases as tumor cells accumulate mutations. Distinct clones within the tumor are indicated by different colors. Although most prostate tumors respond to androgen-deprivation therapy, as shown by the loss of some clones (blue and green) and reduction of others (yellow), they may contain castration-resistant stem cells (indicated by ' $S$ ') that can survive androgen deprivation and propagate castration-resistant prostate cancer. As the clonal architecture of the tumor evolves during progression, depicted by the emergence of castration-resistant clones (orange and red), the cancer stem cells that propagate the tumor may also evolve. 
the human prostate lacks overt lobular structure. Instead, the human prostate displays a zonal architecture at the histological level, being composed of peripheral, transition, and central zones, with most prostate cancers originating in the peripheral zone (McNeal et al. 1988). In certain GEM models, the tumor phenotype may vary between prostate lobes, but overall there does not appear to be a specific lobe that more accurately recapitulates human prostate cancer (Ittmann et al. 2013).

Several additional limitations of GEM models of prostate cancer reflect the current state of the art and are likely to be overcome by future technical improvements. At present, many current GEM models utilize androgendependent promoters, frequently the Probasin promoter or a modified derivative such as the $A R R_{2} P B$ promoter used in the commonly used PB-Cre4 driver (Wu et al. 2001). However, the use of such androgen-dependent promoters has posed a challenge for the modeling of the emergence of castration-resistant disease, because androgen deprivation eliminates driver expression (Irshad \& Abate-Shen 2013). Furthermore, it has been relatively difficult to model metastatic prostate cancer, particularly bone metastasis, which is a major metastatic site in human patients (Irshad \& Abate-Shen 2013). Finally, the frequent chromosomal rearrangements and extensive intratumoral heterogeneity observed in advanced human prostate cancers are not observed in many GEM prostate cancer models (Bianchi-Frias et al. 2015, Wanjala et al. 2015). However, a recent study has reported high frequencies of genomic alterations and intratumoral heterogeneity in the PB-Cre4; Ptenflox/flox; Trp5 $3^{f l o x / f l o x}$ model (Wanjala et al. 2015). This GEM model may therefore be useful for investigating the extensive intratumoral heterogeneity and clonal evolution typically observed in metastatic human prostate cancers (Gundem et al. 2015, Hong et al. 2015, Shen 2015).

\section{Cancer stem cells in GEM models of prostate cancer}

To date, candidate cancer stem cell populations have been identified in several prostate cancer GEM models using cell culture and/or grafting assays. One cell population of particular interest has been the $\mathrm{Lin}^{-} \mathrm{Sca}-1^{+} \mathrm{CD} 49 \mathrm{f}^{\text {high }}$ (LSC ${ }^{\text {high }}$ ) population, based on the original finding that WT LSC ${ }^{\text {high }}$ cells display stem cell properties (Lawson et al. 2007). In particular, the percentage of $\mathrm{Sca}^{+}$and $\mathrm{LSC}^{\text {high }}$ cells increases with disease progression in the PB-Cre4; $P_{t e n}{ }^{\text {flox/flox }}$ model of high-grade PIN and prostate cancer (Wang et al. 2006, Mulholland et al. 2009), and LSC ${ }^{\text {high }}$ cells from PB-Cre4; Pten flox/flox prostates form larger prostaspheres than controls (Mulholland et al. 2009). In addition, LSC ${ }^{\text {high }}$ cells display tumor-propagating activity after sorting and recombining with WT urogenital sinus mesenchyme in renal grafts (Mulholland et al. 2009). Furthermore, isolation of cells that express high levels of CD166 (ALCAM) from the LSC ${ }^{\text {high }}$ population further enriches for tumor prostasphere formation (Jiao et al. 2012).

The identity of putative cancer stem cells has also been investigated in more aggressive GEM models of prostate cancer. Thus, tumor cells from PB-Cre4; Pten flox/flox; Trp53 $3^{\text {flox/flox }}$ mice, which rapidly develop lethal prostate adenocarcinomas that are non-metastatic, form prostaspheres of greater size, have increased efficiencies of colony formation, and develop tumors upon orthotopic transplantation (Abou-Kheir et al. 2010). Similarly, LSC $C^{\text {high }}$ cells from PB-Cre4; Pten flox/flox; Kras ${ }^{L S L-G 12 D /+}$ prostates, which generate invasive and metastatic prostate tumors, display increased prostasphere formation compared to LSC $^{\text {high }}$ cells from PB-Cre4; Pten ${ }^{\text {flox/flox }}$ prostates (Mulholland et al. 2012). After orthotopic injection of prostasphere cells established from PB-Cre4; Pten flox/flox; Kras ${ }^{L L L-G 12 D /+}$ LSC $^{\text {high }}$ cells into immunodeficient recipients, the resulting grafts form poorly differentiated carcinomas and metastases that recapitulate the original tumor phenotype (Mulholland et al. 2012). A recent study showed that expression of a vimentin-GFP reporter in PB-Cre4; Pten $^{\text {flox/flox }}$; Kras ${ }^{L S L-G 12 D /+}$ animals can be used to isolate tumor cells with mesenchymal features, as well as tumor cells harboring both epithelial and mesenchymal characteristics, which are termed 'epithelial-mesenchymal transition' (EMT) tumor cells (Ruscetti et al. 2015). Both mesenchymal-like tumor cells and EMT tumor cells display a tumor-initiating capability, suggesting that these populations also contain cells with cancer stem cell properties (Ruscetti et al. 2015). Finally, studies of $\mathrm{Kras}^{L S L-G 12 \mathrm{D} /+}$ prostate cells infected with lentiviruses overexpressing Cre and $A R$ indicate that epigenetic mechanisms, such as the increased expression of Ezh2, promote tumor-propagation and secondary tumor growth (Cai et al. 2012).

Several GEM models of prostate cancer develop castration-resistant tumors in response to androgen deprivation and have been used for studies of castrationresistant cancer stem cells. In particular, tumors in $P B$ Cre4; Pten ${ }^{\text {flox/flox }}$ mice initially regress in response to castration but subsequently regrow tumors that are castration resistant, which is associated with an increase in the percentage of LSC ${ }^{\text {high }}$ cells (Mulholland et al. 2009).

Published by Bioscientifica Ltd. 
Moreover, the CD166 ${ }^{\text {high }}$ population is also expanded in prostates from castrated PB-Cre4; Pten ${ }^{\text {flox/flox }}$ mice, consistent with the up-regulation of CD166 expression in human castration-resistant prostate cancer (Jiao et al. 2012). Finally, the existence of castration-resistant stem-like cells that have basal or intermediate phenotypes in the proximal region of PB-Cre4; Pten flox/flox $^{\text {for }}$ prostates is supported by analyses of PB-Cre4; Pten flox/flox; $A R^{f l o x / Y}$ animals lacking $\mathrm{AR}$ transcription factor activity (Mulholland et al. 2011).

Taken together, these studies suggest the frequency of tumor-propagating cells increases with tumor progression and with tumor severity and supports the cancer stem cell properties of the LSC ${ }^{\text {high }}$ population. However, the basal phenotype of LSC ${ }^{\text {high }}$ cells in the normal prostate epithelium raises questions about the specific properties of this population in prostate tumors, which should have a luminal phenotype. One possible explanation is that there is a significant increase in the percentage of intermediate cells that co-express basal and luminal markers in GEM models with Pten inactivation (Mulholland et al. 2011, Wang et al. 2013) and may harbor LSC ${ }^{\text {high }}$ cells. Furthermore, the strong bias of the prostasphere assay for growth of basal cells (Wang et al. 2013, Huang et al. 2015) would also be consistent with the identification of LSC $^{\text {high }}$ cells from GEM models. Thus, the identification of additional candidate markers for cancer stem cells is important for clarifying the role and identity of putative cancer stem cells in GEM models of prostate cancer.

Notably, several other genes that are candidate markers for stem/progenitor cells in the normal prostate epithelium have also been proposed to serve as markers for castration-resistant cancer stem cells. For example, increased expression of Sca1, CD133, and c-kit has been observed after the castration of TRAMP transgenic mice, which have a minimal probasin promoter driving expression of SV40 large and small T-antigens and develop adenocarcinoma and neuroendocrine tumors, as well as castration-resistant disease (Gingrich et al. 1997, Chiaverotti et al. 2008). In addition, expression of Sox 2 appears to mark a luminal castration-resistant stem cell population in human prostate tumors and is increased in PB-Cre4, Pten flox/flox mouse tumors after castration (Bae et al. 2010, Kregel et al. 2013, Wang et al. 2014a). Another candidate cancer stem marker for a luminal castration-resistant population is $N k \times 3.1$, which is expressed in rare castration-resistant Nkx3.1 expressing cells (CARNs) (Wang et al. 2009), while human CARN-like cells that survive castration have been identified in BM18 human prostate cancer xenografts
(Germann et al. 2012). However, functional studies evaluating tumor-propagating abilities have not yet been conducted on all of these populations that have been identified using these markers.

\section{Role of tumor microenvironment and the cancer stem cell niche}

In a normal untransformed tissue, stem cell activity is regulated by the surrounding microenvironment, or niche. In the case of the prostate, the stem cell niche has not been identified, although there is evidence that a stem/ progenitor population resides in the proximal prostate (Tsujimura et al. 2002, Burger et al. 2005, Xin et al. 2005, Goto et al. 2006). In principle, however, the functional properties of cancer stem cells may be influenced by the tissue microenvironment and the presence or absence of the endogenous niche (Medema 2013).

For example, evidence for a role of the microenvironment is provided by the PB-Cre4; Trp53 flox/flox; $R b^{\text {flox/flox }}$ model, which develops aggressive tumors with both luminal and neuroendocrine features in the proximal but not distal prostate (Zhou et al. 2007). Interestingly, both proximal and distal cells gave rise to tumors in assays in which dissociated epithelial cells were injected subcutaneously together with Matrigel into SCID mice, suggesting a possible effect of the tissue microenvironment in suppressing distal tumorigenesis in this GEM model (Zhou et al. 2007). Conversely, the tissue microenvironment may also be disrupted during tumor progression, which may affect the localization of stem/progenitor cells. Thus, LSC $^{\text {high }}$ cells have a basal location in nonmutant prostates, but tumor LSC ${ }^{\text {high }}$ cells from PB-Cre4; Pten flox/flox prostates are in both basal and luminal locations (Mulholland et al. 2009).

An additional study has provided evidence that functional effects of the tissue microenvironment on tumor-propagating cells can be exerted by stromal components. In particular, prostasphere formation by LSC $^{\text {high }}$ cells from PB-Cre4; Pten flox/flox tumors is increased by co-culture with normal primary stromal cells or urogenital sinus mesenchyme and further enhanced by co-culture with cancer associated fibroblasts (CAFs) (Liao et al. 2010). In addition, the PB-Cre4; Pten flox/flox LSC $^{\text {high }}$ cells form highly proliferative tumor-like glandular structures more efficiently in renal grafts after recombination with CAFs than with normal prostate fibroblasts (Liao et al. 2010). To date, several distinct stromal subtypes, including a Gli1-expressing stromal stem cell population, have been defined in the normal mouse prostate (Peng

Published by Bioscientifica Ltd. 
et al. 2013), but more studies are required for functional characterization of stromal populations in both the normal and the transformed prostate and to identify putative stromal signals that influence tumor propagation. As a cautionary note, these findings also suggest that results from cell culture and transplantation assays in which putative cancer stem cells are isolated from their native microenvironment should be interpreted with caution.

\section{Current challenges and future directions}

It is important to emphasize that the identification of cancer stem cells is limited by the functional assays available for their detection. However, the methods used for the isolation and analysis of cancer stem cells can generate inherent biases. In particular, the dissociation of tumor cells for flow cytometry and further analysis can result in a bias for cells that are robust enough to survive the dissociation methods (Kreso \& Dick 2014). Furthermore, if the dissociated tumor cells are cultured in vitro or transplanted to assay tumor propagation, they will also undergo selection for cells able to grow in the specific conditions utilized.

Notably, a major obstacle in the analysis of prostate cancer stem cells has been the severe difficulties encountered in growing prostate cells with a luminal phenotype (Peehl 2005). Although constitutive expression of the Notch1 intracellular domain can suppress anoikis and promote survival of some prostate luminal cells in prostasphere assays (Kwon et al. 2014b), prostasphere assays are highly biased toward the growth of basal cells (Wang et al. 2013, Huang et al. 2015). Thus, a significant recent technological advance has been the development of two independent culture systems that can promote growth of luminal cells into three-dimensional organoids (Chua et al. 2014, Gao et al. 2014, Karthaus et al. 2014). Both of these culture conditions support the long-term growth of mouse and human prostate tumor cells and should allow the identification and functional analysis of luminal cancer stem cells. Nonetheless, experimental findings using organoid systems will require validation using in vivo approaches and should be viewed as complementary to results obtained using GEM models.

In addition, although transplantation/grafting assays represent highly important approaches for functional analyses of candidate cancer stem cells, these assays test the potential of cells to propagate tumors, and not their actual fate (Magee et al. 2012). With respect to the normal prostate, stem cell properties can be highly assay- dependent and may not reflect in vivo activities (Choi et al. 2012, Wang et al. 2013). Consequently, it is essential to pursue in vivo studies of prostate cancer stem cells in GEM models to establish their endogenous role in tumor propagation (Fig. 1). In particular, lineage-tracing, clonal analyses, and cell ablation studies have provided evidence for cancer stem cells in solid tumors of the brain, skin, and intestine (Chen et al. 2012, Driessens et al. 2012, Schepers et al. 2012, Oshimori et al. 2015). Lineage-tracing studies of metastasis in suitable GEM models, such the Nkx3.1 ${ }^{\text {CreERT2/+ }} ;$ Pten $^{\text {flox/flox }} ; \mathrm{Kras}^{\text {LSL-G12D/+ }}$ model (Aytes et al. 2013), would also be useful to determine whether cancer stem cells have the potential to serve as metastasisinitiating cells. Interestingly, however, recent studies provide evidence for polyclonal metastases in prostate cancer patients, suggesting that metastases might be seeded by multiple cells (Gundem et al. 2015, Shen 2015) and raising the possibility that tumor-propagating activity may itself require cooperative interactions between different cell types (Marusyk et al. 2014).

Finally, it is evident that additional markers for cancer stem cells will need to be identified, particularly those that are conserved between mouse and human. For example, candidate markers may emerge from next-generation sequencing efforts of mouse and human prostate tumors, as well as from molecular analyses of candidate cancer stem cell populations identified in GEM models. Such studies could lead to the identification of new cell surface markers that will enable functional analyses of intratumor heterogeneity, as well as biomarkers with potential clinical utility. In particular, biomarkers for castration-resistant stem cells could potentially distinguish indolent from aggressive disease and thereby decrease the overtreatment of indolent prostate tumors, which represents a major clinical challenge.

Declaration of interest

The authors declare that there is no conflict of interest that could be perceived as prejudicing the impartiality of this review.

\section{Funding}

This work was supported by NIH grants K99 CA194287 (M Shibata) and P01 CA154293 (M M Shen).

\section{References}

Abou-Kheir WG, Hynes PG, Martin PL, Pierce R \& Kelly K 2010 Characterizing the contribution of stem/progenitor cells to tumorigenesis in the Pten ${ }^{-/-}$TP $3^{-/-}$prostate cancer model. Stem Cells 28 2129-2140. (doi:10.1002/stem.538)

Published by Bioscientifica Ltd. 
Abrahamsson PA \& di Sant'Agnese PA 1993 Neuroendocrine cells in the human prostate gland. Journal of Andrology 14 307-309.

Anderson K, Lutz C, van Delft FW, Bateman CM, Guo Y, Colman SM, Kempski H, Moorman AV, Titley I, Swansbury J et al. 2011 Genetic variegation of clonal architecture and propagating cells in leukaemia. Nature 469 356-361. (doi:10.1038/nature09650)

Aytes A, Mitrofanova A, Kinkade CW, Lefebvre C, Lei M, Phelan V, LeKaye HC, Koutcher JA, Cardiff RD, Califano A et al. 2013 ETV4 promotes metastasis in response to activation of PI3-kinase and Ras signaling in a mouse model of advanced prostate cancer. PNAS 110 E3506-E3515. (doi:10.1073/pnas.1303558110)

Baca SC, Prandi D, Lawrence MS, Mosquera JM, Romanel A, Drier Y, Park K, Kitabayashi N, Macdonald TY, Ghandi M et al. 2013 Punctuated evolution of prostate cancer genomes. Cell 153 666-677. (doi:10.1016/ j.cell.2013.03.021)

Bae KM, Su Z, Frye C, McClellan S, Allan RW, Andrejewski JT, Kelley V, Jorgensen M, Steindler DA, Vieweg J et al. 2010 Expression of pluripotent stem cell reprogramming factors by prostate tumor initiating cells. Journal of Urology 183 2045-2053. (doi:10.1016/j.juro. 2009.12.092)

Barbieri CE, Baca SC, Lawrence MS, Demichelis F, Blattner M, Theurillat JP, White TA, Stojanov P, Van Allen E, Stransky N et al. 2012 Exome sequencing identifies recurrent SPOP, FOXA1 and MED12 mutations in prostate cancer. Nature Genetics 44 685-689. (doi:10.1038/ng.2279)

Bianchi-Frias D, Hernandez SA, Coleman R, Wu H \& Nelson PS 2015 The landscape of somatic chromosomal copy number aberrations in GEM models of prostate carcinoma. Molecular Cancer Research 13 339-347. (doi:10.1158/1541-7786.MCR-14-0262)

Blanpain C 2013 Tracing the cellular origin of cancer. Nature Cell Biology $\mathbf{1 5}$ 126-134. (doi:10.1038/ncb2657)

Brawer MK, Peehl DM, Stamey TA \& Bostwick DG 1985 Keratin immunoreactivity in the benign and neoplastic human prostate. Cancer Research 45 3663-3667.

Burger PE, Xiong X, Coetzee S, Salm SN, Moscatelli D, Goto K \& Wilson EL 2005 Sca-1 expression identifies stem cells in the proximal region of prostatic ducts with high capacity to reconstitute prostatic tissue. PNAS 102 7180-7185. (doi:10.1073/pnas.0502761102)

Cai H, Memarzadeh S, Stoyanova T, Beharry Z, Kraft AS \& Witte ON 2012 Collaboration of Kras and androgen receptor signaling stimulates EZH2 expression and tumor-propagating cells in prostate cancer. Cancer Research 72 4672-4681. (doi:10.1158/0008-5472.CAN-12-0228)

Chen J, Li Y, Yu TS, McKay RM, Burns DK, Kernie SG \& Parada LF 2012 A restricted cell population propagates glioblastoma growth after chemotherapy. Nature 488 522-526. (doi:10.1038/nature11287)

Chen X, Rycaj K, Liu X \& Tang DG 2013 New insights into prostate cancer stem cells. Cell Cycle 12 579-586. (doi:10.4161/cc.23721)

Chiaverotti T, Couto SS, Donjacour A, Mao JH, Nagase H, Cardiff RD, Cunha GR \& Balmain A 2008 Dissociation of epithelial and neuroendocrine carcinoma lineages in the transgenic adenocarcinoma of mouse prostate model of prostate cancer. American Journal of Pathology 172 236-246. (doi:10.2353/ajpath.2008.070602)

Choi N, Zhang B, Zhang L, Ittmann M \& Xin L 2012 Adult murine prostate basal and luminal cells are self-sustained lineages that can both serve as targets for prostate cancer initiation. Cancer Cell 21 253-265. (doi:10. 1016/j.ccr.2012.01.005)

Chua CW, Shibata M, Lei M, Toivanen R, Barlow LJ, Bergren SK, Badani KK, McKiernan JM, Benson MC, Hibshoosh H et al. 2014 Single luminal epithelial progenitors can generate prostate organoids in culture. Nature Cell Biology 16 951-961. (doi:10.1038/ncb3047)

De Marzo AM, Meeker AK, Epstein JI \& Coffey DS 1998 Prostate stem cell compartments: expression of the cell cycle inhibitor p27Kip1 in normal, hyperplastic, and neoplastic cells. American Journal of Pathology 153 911-919. (doi:10.1016/S0002-9440(10)65632-5)

Driessens G, Beck B, Caauwe A, Simons BD \& Blanpain C 2012 Defining the mode of tumour growth by clonal analysis. Nature $\mathbf{4 8 8} 527-530$. (doi:10.1038/nature11344)
Evans GS \& Chandler JA 1987 Cell proliferation studies in the rat prostate: II. The effects of castration and androgen-induced regeneration upon basal and secretory cell proliferation. Prostate 11 339-351. (doi:10.1002/pros.2990110406)

Gao D, Vela I, Sboner A, Iaquinta PJ, Karthaus WR, Gopalan A, Dowling C, Wanjala JN, Undvall EA, Arora VK et al. 2014 Organoid cultures derived from patients with advanced prostate cancer. Cell 159 176-187. (doi:10.1016/j.cell.2014.08.016)

Garraway IP, Sun W, Tran CP, Perner S, Zhang B, Goldstein AS, Hahm SA, Haider M, Head CS, Reiter RE et al. 2010 Human prostate sphereforming cells represent a subset of basal epithelial cells capable of glandular regeneration in vivo. Prostate 70 491-501. (doi:10.1002/pros. 21083)

Germann M, Wetterwald A, Guzman-Ramirez N, van der Pluijm G, Culig Z, Cecchini MG, Williams ED \& Thalmann GN 2012 Stem-like cells with luminal progenitor phenotype survive castration in human prostate cancer. Stem Cells 30 1076-1086. (doi:10.1002/stem.1087)

Gingrich JR, Barrios RJ, Kattan MW, Nahm HS, Finegold MJ \& Greenberg NM 1997 Androgen-independent prostate cancer progression in the TRAMP model. Cancer Research 57 4687-4691.

Goldstein AS, Lawson DA, Cheng D, Sun W, Garraway IP \& Witte ON 2008 Trop2 identifies a subpopulation of murine and human prostate basal cells with stem cell characteristics. PNAS 105 20882-20887. (doi:10.1073/pnas.0811411106)

Goldstein AS, Huang J, Guo C, Garraway IP \& Witte ON $2010 a$ Identification of a cell of origin for human prostate cancer. Science 329 568-571. (doi:10.1126/science.1189992)

Goldstein AS, Stoyanova T \& Witte ON 2010 $b$ Primitive origins of prostate cancer: in vivo evidence for prostate-regenerating cells and prostate cancer-initiating cells. Molecular Oncology 4 385-396. (doi:10.1016/j. molonc.2010.06.009)

Goto K, Salm SN, Coetzee S, Xiong X, Burger PE, Shapiro E, Lepor H, Moscatelli D \& Wilson EL 2006 Proximal prostatic stem cells are programmed to regenerate a proximal-distal ductal axis. Stem Cells $\mathbf{2 4}$ 1859-1868. (doi:10.1634/stemcells.2005-0585)

Greaves M \& Maley CC 2012 Clonal evolution in cancer. Nature 481 306-313. (doi:10.1038/nature10762)

Gundem G, Van Loo P, Kremeyer B, Alexandrov LB, Tubio JM, Papaemmanuil E, Brewer DS, Kallio HM, Hognas G, Annala M et al. 2015 The evolutionary history of lethal metastatic prostate cancer. Nature 520 353-357. (doi:10.1038/nature14347)

Hong MK, Macintyre G, Wedge DC, Van Loo P, Patel K, Lunke S, Alexandrov LB, Sloggett C, Cmero M, Marass F et al. 2015 Tracking the origins and drivers of subclonal metastatic expansion in prostate cancer. Nature Communications 6 6605. (doi:10.1038/ncomms7605)

Huang Y, Hamana T, Liu J, Wang C, An L, You P, Chang JY, Xu J, McKeehan WL \& Wang F 2015 Prostate sphere-forming stem cells are derived from the P63-expressing basal compartment. Journal of Biological Chemistry 290 17745-17752. (doi:10.1074/jbc.M115.661033)

Irshad S \& Abate-Shen C 2013 Modeling prostate cancer in mice: something old, something new, something premalignant, something metastatic. Cancer Metastasis Reviews 32 109-122. (doi:10.1007/s10555012-9409-1)

Isaacs JT 1985 Control of cell proliferation and cell death in the normal and neoplastic prostate: a stem cell model. In Benign Prostatic Hyperplasia, pp 85-94. Eds CH Rodgers, DS Coffey, G Cunha, JT Grayshack, R Henman \& R Horton. Washington, DC: Department of Helath and Human Services.

Isaacs JT, Lundmo PI, Berges R, Martikainen P, Kyprianou N \& English HF 1992 Androgen regulation of programmed death of normal and malignant prostatic cells. Journal of Andrology 13 457-464.

Ittmann M, Huang J, Radaelli E, Martin P, Signoretti S, Sullivan R, Simons BW, Ward JM, Robinson BD, Chu GC et al. 2013 Animal models of human prostate cancer: the consensus report of the New York meeting of the Mouse Models of Human Cancers Consortium Prostate 
Pathology Committee. Cancer Research 73 2718-2736. (doi:10.1158/ 0008-5472.CAN-12-4213)

Jiao J, Hindoyan A, Wang S, Tran LM, Goldstein AS, Lawson D, Chen D, Li Y, Guo C, Zhang B et al. 2012 Identification of CD166 as a surface marker for enriching prostate stem/progenitor and cancer initiating cells. PLoS ONE 7 e42564. (doi:10.1371/journal.pone.0042564)

Karthaus WR, Iaquinta PJ, Drost J, Gracanin A, van Boxtel R, Wongvipat J, Dowling CM, Gao D, Begthel H, Sachs N et al. 2014 Identification of multipotent luminal progenitor cells in human prostate organoid cultures. Cell 159 163-175. (doi:10.1016/j.cell.2014.08.017)

Kregel S, Kiriluk KJ, Rosen AM, Cai Y, Reyes EE, Otto KB, Tom W, Paner GP, Szmulewitz RZ \& Vander Griend DJ 2013 Sox2 is an androgen receptorrepressed gene that promotes castration-resistant prostate cancer. PLoS ONE 8 e53701. (doi:10.1371/journal.pone.0053701)

Kreso A \& Dick JE 2014 Evolution of the cancer stem cell model. Cell Stem Cell 14 275-291. (doi:10.1016/j.stem.2014.02.006)

Kwon OJ, Zhang L, Ittmann MM \& Xin L 2014a Prostatic inflammation enhances basal-to-luminal differentiation and accelerates initiation of prostate cancer with a basal cell origin. PNAS 111 E592-E600. (doi:10. 1073/pnas.1318157111)

Kwon OJ, Valdez JM, Zhang L, Zhang B, Wei X, Su Q, Ittmann MM, Creighton CJ \& Xin L $2014 b$ Increased Notch signalling inhibits anoikis and stimulates proliferation of prostate luminal epithelial cells. Nature Communications 5 4416. (doi:10.1038/ncomms5416)

Lawrence MG, Taylor RA, Toivanen R, Pedersen J, Norden S, Pook DW, Frydenberg M, Papargiris MM, Niranjan B, Richards MG et al. 2013 A preclinical xenograft model of prostate cancer using human tumors. Nature Protocols 8 836-848. (doi:10.1038/nprot.2013.043)

Lawson DA, Xin L, Lukacs RU, Cheng D \& Witte ON 2007 Isolation and functional characterization of murine prostate stem cells. PNAS $\mathbf{1 0 4}$ 181-186. (doi:10.1073/pnas.0609684104)

Lawson DA, Zong Y, Memarzadeh S, Xin L, Huang J \& Witte ON 2010 Basal epithelial stem cells are efficient targets for prostate cancer initiation. PNAS 107 2610-2615. (doi:10.1073/pnas.0913873107)

Lee DK, Liu Y, Liao L, Wang F \& Xu J 2014 The prostate basal cell (BC) heterogeneity and the p63-positive BC differentiation spectrum in mice. International Journal of Biological Sciences 10 1007-1017. (doi:10.7150/ijbs.9997)

Li H, Jiang M, Honorio S, Patrawala L, Jeter CR, Calhoun-Davis T, Hayward SW \& Tang DG 2009 Methodologies in assaying prostate cancer stem cells. Methods in Molecular Biology 568 85-138. (doi:10.007/ 978-1-59745-280-9)

Liao CP, Adisetiyo H, Liang M \& Roy-Burman P 2010 Cancer-associated fibroblasts enhance the gland-forming capability of prostate cancer stem cells. Cancer Research 70 7294-7303. (doi:10.1158/0008-5472. CAN-09-3982)

Liu J, Pascal LE, Isharwal S, Metzger D, Ramos Garcia R, Pilch J, Kasper S, Williams K, Basse PH, Nelson JB et al. 2011 Regenerated luminal epithelial cells are derived from preexisting luminal epithelial cells in adult mouse prostate. Molecular Endocrinology 25 1849-1857. (doi:10. 1210/me.2011-1081)

Lu TL, Huang YF, You LR, Chao NC, Su FY, Chang JL \& Chen CM 2013 Conditionally ablated Pten in prostate basal cells promotes basalto-luminal differentiation and causes invasive prostate cancer in mice. American Journal of Pathology 182 975-991. (doi:10.1016/j.ajpath.2012. 11.025)

Lukacs RU, Goldstein AS, Lawson DA, Cheng D \& Witte ON 2010 Isolation, cultivation and characterization of adult murine prostate stem cells. Nature Protocols 5 702-713. (doi:10.1038/nprot.2010.11)

Magee JA, Piskounova E \& Morrison SJ 2012 Cancer stem cells: impact, heterogeneity, and uncertainty. Cancer Cell 21 283-296. (doi:10.1016/j. ccr.2012.03.003)

Maitland NJ, Frame FM, Polson ES, Lewis JL \& Collins AT 2011 Prostate cancer stem cells: do they have a basal or luminal phenotype? Hormones \& Cancer 2 47-61. (doi:10.1007/s12672-010-0058-y)
Marusyk A, Tabassum DP, Altrock PM, Almendro V, Michor F \& Polyak K 2014 Non-cell-autonomous driving of tumour growth supports sub-clonal heterogeneity. Nature 514 54-58. (doi:10.1038/ nature13556)

McNeal JE, Redwine EA, Freiha FS \& Stamey TA 1988 Zonal distribution of prostatic adenocarcinoma. Correlation with histologic pattern and direction of spread. American Journal of Surgical Pathology 12 897-906. (doi:10.1097/00000478-198812000-00001)

Medema JP 2013 Cancer stem cells: the challenges ahead. Nature Cell Biology 15 338-344. (doi:10.1038/ncb2717)

Mulholland DJ, Xin L, Morim A, Lawson D, Witte O \& Wu H 2009 Lin ${ }^{-}$Sca- $1^{+}$CD49fhigh stem/progenitors are tumor-initiating cells in the Pten-null prostate cancer model. Cancer Research 69 8555-8562. (doi:10.1158/0008-5472.CAN-08-4673)

Mulholland DJ, Tran LM, Li Y, Cai H, Morim A, Wang S, Plaisier S, Garraway IP, Huang J, Graeber TG et al. 2011 Cell autonomous role of PTEN in regulating castration-resistant prostate cancer growth. Cancer Cell 19 792-804. (doi:10.1016/j.ccr.2011.05.006)

Mulholland DJ, Kobayashi N, Ruscetti M, Zhi A, Tran LM, Huang J, Gleave M \& Wu H 2012 Pten loss and RAS/MAPK activation cooperate to promote EMT and metastasis initiated from prostate cancer stem/progenitor cells. Cancer Research 72 1878-1889. (doi:10.1158/ 0008-5472.CAN-11-3132)

Oshimori N, Oristian D \& Fuchs E 2015 TGF $\beta$ promotes heterogeneity and drug resistance in squamous cell carcinoma. Cell $160963-976$ (doi:10.1016/j.cell.2015.01.043)

Ousset M, Van Keymeulen A, Bouvencourt G, Sharma N, Achouri Y, Simons BD \& Blanpain C 2012 Multipotent and unipotent progenitors contribute to prostate postnatal development. Nature Cell Biology $\mathbf{1 4}$ 1131-1138. (doi:10.1038/ncb2600)

Peehl DM 2005 Primary cell cultures as models of prostate cancer development. Endocrine-Related Cancer 12 19-47. (doi:10.1677/erc.1. 00795)

Peng YC, Levine CM, Zahid S, Wilson EL \& Joyner AL 2013 Sonic hedgehog signals to multiple prostate stromal stem cells that replenish distinct stromal subtypes during regeneration. PNAS 110 20611-20616. (doi:10.1073/pnas.1315729110)

Pignon JC, Grisanzio C, Geng Y, Song J, Shivdasani RA \& Signoretti S 2013 p63-expressing cells are the stem cells of developing prostate, bladder, and colorectal epithelia. PNAS 110 8105-8110. (doi:10.1073/pnas. 1221216110)

Robinson D, Van Allen EM, Wu YM, Schultz N, Lonigro RJ, Mosquera JM, Montgomery B, Taplin ME, Pritchard CC, Attard G et al. 2015 Integrative clinical genomics of advanced prostate cancer. Cell $\mathbf{1 6 1}$ 1215-1228. (doi:10.1016/j.cell.2015.05.001)

Ruscetti M, Quach B, Dadashian EL, Mulholland DJ \& Wu H 2015 Tracking and functional characterization of epithelial-mesenchymal transition and mesenchymal tumor cells during prostate cancer metastasis. Cancer Research 75 2749-2759. (doi:10.1158/0008-5472.CAN-14-3476)

Schepers AG, Snippert HJ, Stange DE, van den Born M, van Es JH, van de Wetering M \& Clevers H 2012 Lineage tracing reveals Lgr5 $^{+}$stem cell activity in mouse intestinal adenomas. Science 337 730-735. (doi:10.1126/science.1224676)

Shappell SB, Thomas GV, Roberts RL, Herbert R, Ittmann MM, Rubin MA Humphrey PA, Sundberg JP, Rozengurt N, Barrios R et al. 2004 Prostate pathology of genetically engineered mice: definitions and classification. The consensus report from the Bar Harbor meeting of the Mouse Models of Human Cancer Consortium Prostate Pathology Committee. Cancer Research 64 2270-2305. (doi:10.1158/0008-5472. CAN-03-0946)

Shen MM 2015 Cancer: The complex seeds of metastasis. Nature $\mathbf{5 2 0}$ 298-299. (doi:10.1038/nature14377)

Shen MM \& Abate-Shen C 2010 Molecular genetics of prostate cancer: new prospects for old challenges. Genes and Development 24 1967-2000. (doi:10.1101/gad.1965810) 
Shibata M \& Shen MM 2013 The roots of cancer: stem cells and the basis for tumor heterogeneity. BioEssays: News and Reviews in Molecular, Cellular and Developmental Biology 35 253-260. (doi:10.1002/bies.201200101)

Taylor BS, Schultz N, Hieronymus H, Gopalan A, Xiao Y, Carver BS, Arora VK, Kaushik P, Cerami E, Reva B et al. 2010 Integrative genomic profiling of human prostate cancer. Cancer Cell 18 11-22. (doi:10.1016/ j.ccr.2010.05.026)

Terry S \& Beltran H 2014 The many faces of neuroendocrine differentiation in prostate cancer progression. Frontiers in Oncology 4 60. (doi:10.3389/ fonc.2014.00060)

Toivanen R, Frydenberg M, Murphy D, Pedersen J, Ryan A, Pook D, Berman DM, Taylor RA \& Risbridger GP 2013 A preclinical xenograft model identifies castration-tolerant cancer-repopulating cells in localized prostate tumors. Science Translational Medicine 5 187ra171. (doi:10.1126/scitranslmed.3005688)

Tsujimura A, Koikawa Y, Salm S, Takao T, Coetzee S, Moscatelli D, Shapiro E, Lepor H, Sun TT \& Wilson EL 2002 Proximal location of mouse prostate epithelial stem cells: a model of prostatic homeostasis. Journal of Cell Biology 157 1257-1265. (doi:10.1083/jcb.200202067)

Visvader JE 2011 Cells of origin in cancer. Nature 469 314-322. (doi:10.1038/nature09781)

Wang ZA \& Shen MM 2011 Revisiting the concept of cancer stem cells in prostate cancer. Oncogene 30 1261-1271. (doi:10.1038/onc.2010.530)

Wang S, Garcia AJ, Wu M, Lawson DA, Witte ON \& Wu H 2006 Pten deletion leads to the expansion of a prostatic stem/progenitor cell subpopulation and tumor initiation. PNAS 103 1480-1485. (doi:10.1073/pnas.0510652103)

Wang X, Kruithof-de Julio M, Economides KD, Walker D, Yu H, Halili MV, Hu Y-P, Price SM, Abate-Shen C \& Shen MM 2009 A luminal epithelial stem cell that is a cell of origin for prostate cancer. Nature $\mathbf{4 6 1} 495-500$. (doi:10.1038/nature08361)

Wang ZA, Mitrofanova A, Bergren SK, Abate-Shen C, Cardiff RD, Califano A \& Shen MM 2013 Lineage analysis of basal epithelial cells reveals their unexpected plasticity and supports a cell-of-origin model for prostate cancer heterogeneity. Nature Cell Biology 15 274-283. (doi:10.1038/ ncb2697)

Wang J, Zhu HH, Chu M, Liu Y, Zhang C, Liu G, Yang X, Yang R \& Gao WQ $2014 a$ Symmetrical and asymmetrical division analysis provides evidence for a hierarchy of prostate epithelial cell lineages. Nature Communications 5 4758. (doi:10.1038/ncomms5758)

Wang ZA, Toivanen R, Bergren SK, Chambon P \& Shen MM 2014b Luminal cells are favored as the cell of origin for prostate cancer. Cell Reports $\mathbf{8}$ 1339-1346. (doi:10.1016/j.celrep.2014.08.002)
Wang BE, Wang X, Long JE, Eastham-Anderson J, Firestein R \& Junttila MR 2015 Castration-resistant Lgr5(+) cells are long-lived stem cells required for prostatic regeneration. Stem Cell Reports 4 768-779. (doi:10.1016/j.stemcr.2015.04.003)

Wanjala J, Taylor BS, Chapinski C, Hieronymus H, Wongvipat J, Chen Y, Nanjangud GJ, Schultz N, Xie Y, Liu S et al. 2015 Identifying actionable targets through integrative analyses of GEM model and human prostate cancer genomic profiling. Molecular Cancer Therapeutics 14 278-288. (doi:10.1158/1535-7163.MCT-14-0542-T)

Weinstein MH, Signoretti S \& Loda M 2002 Diagnostic utility of immunohistochemical staining for p63, a sensitive marker of prostatic basal cells. Modern Pathology 15 1302-1308. (doi:10.1097/01.MP. $0000038460.95912 .6 \mathrm{E})$

Wojno KJ \& Epstein JI 1995 The utility of basal cell-specific anti-cytokeratin antibody (34ßE12) in the diagnosis of prostate cancer. A review of 228 cases. American Journal of Surgical Pathology 19 251-260. (doi:10.1097/ 00000478-199503000-00002)

Wu X, Wu J, Huang J, Powell WC, Zhang J, Matusik RJ, Sangiorgi FO, Maxson RE, Sucov HM \& Roy-Burman P 2001 Generation of a prostate epithelial cell-specific Cre transgenic mouse model for tissue-specific gene ablation. Mechanisms of Development 101 61-69. (doi:10.1016/ S0925-4773(00)00551-7)

Xin L, Ide H, Kim Y, Dubey P \& Witte ON 2003 In vivo regeneration of murine prostate from dissociated cell populations of postnatal epithelia and urogenital sinus mesenchyme. PNAS 100 (Suppl 1) 11896-11903. (doi:10.1073/pnas.1734139100)

Xin L, Lawson DA \& Witte ON 2005 The Sca-1 cell surface marker enriches for a prostate-regenerating cell subpopulation that can initiate prostate tumorigenesis. PNAS 102 6942-6947. (doi:10.1073/pnas. 0502320102)

Xin L, Lukacs RU, Lawson DA, Cheng D \& Witte ON 2007 Selfrenewal and multilineage differentiation in vitro from murine prostate stem cells. Stem Cells 25 2760-2769. (doi:10.1634/stemcells. 2007-0355)

Xue Y, Smedts F, Debruyne FM, de la Rosette JJ \& Schalken JA 1998 Identification of intermediate cell types by keratin expression in the developing human prostate. Prostate 34 292-301. (doi:10.1002/ (SICI) 1097-0045(19980301)34:4 < 292::AID-PROS7>3.0.CO;2-J)

Zhou Z, Flesken-Nikitin A \& Nikitin AY 2007 Prostate cancer associated with $\mathrm{p} 53$ and $\mathrm{Rb}$ deficiency arises from the stem/progenitor cellenriched proximal region of prostatic ducts. Cancer Research $\mathbf{6 7}$ 5683-5690. (doi:10.1158/0008-5472.CAN-07-0768)

Received in final form 27 August 2015

Accepted 4 September 2015

Made available online as an Accepted Preprint

4 September 2015
(C) 2015 Society for Endocrinology Printed in Great Britain 